sciences, but by the extent to which they each contribute to the environment.

In order to meet the criticism of superficiality and triviality to which all broad schemes of science teaching are subject, the sub-committee referred to has drawn up not only a suggested syllabus, but also a list of fundamental principles of science, the application of which is of fundamental importance in the life of the ordinary citizen, and towards a knowledge of which it is felt that any course of elementary science, whatever its content, should aim. These fundamental principles presented as the aims of the new subject need, and it is hoped will get, criticism and correction by scientific workers, laymen and all interested in educational matters.

It is realised, too, that there are many practical difficulties of method, organisation and teaching, particularly where teachers are by their training of necessity specialists ; but it is felt that with a clear statement of aim and policy, these difficulties will not be insuperable.

What is more controversial is the recommendation of the Investigators, which was agreed to by the Science Masters' Association at the annual general meeting, to make an examination in this subject of elementary science compulsory for all School Certificate candidates, unless they offer all three science subjects, biology, chemistry, physics. But it is felt that, while no brief is held for examinations, as such, so long as they exist they do largely influence the curriculum of the schools, and unless the subject of elementary science, like English and mathematics, is made compulsory, it will not receive serious consideration in competition with other subjects of examinational value. Moreover, much as compulsion is disliked, it is pointed out that compulsion for the science candidate virtually exists at the moment, but confined to a very narrow field of one science, or part of one science. The result of the adoption of compulsory elementary science in School Certificate would broaden both the examination and the school curriculum and thus be of most benefit to what, after all, should be the paramount consideration-the needs of the ordinary pupil.

F. W. TURNER.

\title{
Patents and Inventions
}

$\mathrm{T}$ HE Institution of Mechanical Engineers has recently formed an Inventions Advisory Committee with Mr. W. Taylor as chairman. In connexion with the inauguration of this Committee, on January 26 a meeting of the Institution was held when four short papers were read dealing with invention and inventors. These papers were "The Evolution of Invention", by H. W. Dickinson; "The Inventor", by Dr. H. S. Hatfield; "Provisional Patent Protection and Patent Claims", by Sir William Jarratt and "The Development and Exploitation of Inventions", by A. H. Gledhill.

The subject is a vast one, for as Mr. Dickinson said, "All social, economic, physical, technical, and commercial developments are the result of invention, and we may say that civilization is a synthesis of the inventions made by man since his appearance on this planet a million years ago". The word invention to-day has three meanings : (1) the thing schemed or contrived; (2) the mental processes involved; and (3) the ability to evolve the new scheme or contrivance, commonly called inventiveness. As regards the encouragement of invention, England furnishes the first known instance of encouragement being given to the producer of a new process, for in 1440 (18, Henry VI) Letters Patent were granted by the Crown to John of Schiedam and his company for a method or process of manufacturing salt. It was, however, the Statue of Monopolies of 1624 which formed the basis of our present patent systems.

Dr. Hatfield seems to consider the technical inventor to be a new figure in the history of mankind, but it is doubtful whether this view is correct. The ships, the aqueducts, the tunnels and the buildings of the Romans were the result of the accumulated inventions of the day, and these would have undoubtedly been followed by others had not the Empire been overwhelmed by the barbarians of the north. In concluding his contribution to the symposium, Dr. Hatfield attempted to define the mental characteristics which distinguish the successful inventor.

While the papers of Mr. Dickinson and Dr. Hatfield referred largely to the philosophy of invention, those by Sir William Jarratt and Mr. Gledhill discussed the position of the inventor and of patent legislation to-day. Sir William Jarratt congratulated the Institution on the formation of a Standing Committee to consider inventions submitted by members. Some years ago, he said, he served on a com. mittee appointed to consider the best method of dealing with inventions made by Government servants, and through the report of that committee each of the great Departments of State has now an Awards Cormmittee, with power to recommend monetary awards for inventors. If industry in Great Britain is to maintain and improve its position in the world, it will be necessary that discovery and invention shall continue to be encouraged by public and private benevolence, by research scholarships, by a sound system of patents and by the work of committees such as that of the Institution of Mechanical Engineers.

The last paper, that by Mr. Gledhill, dealt concisely with the commercial development of inventions, the sale of the products of an invention and the manufacturing of the product of an invention. Incidentally, he mentioned that the Patent Office made a net profit of $£ 146,000$ last year, and he suggested that a portion of this might wisely be used to encourage developments of inventions which would benefit the country. It might also be proposed that some of this profit be used to improve the conditions under which the examiners work and for the upkeep of the library, where many books are in need of rebinding and where a system of vacuum cleaning would be advantageous. It may indeed be doubted whether an increase in the facilities for inventors and a reduction of their fees is not a sounder national policy than to look to the Patent Office as a source of revenue.

That there is a need for a continual revision of the patent laws was suggested by several of those who took part in the discussion of the papers. The general interest shown in the discussion is a good augury for a new departure of the Institution, which as the chairman, Col. A. E. Davidson, said, is justified by its Royal Charter, which states that one object of the Institution is "to encourage invention and research in matters connected with mechanical engineering". 